\title{
EVALUATION OF ANTI-TRICHOMONASE ACTIVITIES OF METHANOL EXTRACT OF Hypericum scabrum L. ${ }^{(1)}$
}

\section{Hypericum scabrum L. METHANOL EKSTRAKTININ ANTİ- TRICHOMONAS AKTIVITESININ DEĞERLENDİIILMESI}

\section{Necati OZPINAR ${ }^{1}$, Hulya OZPINAR', Nuraniye ERUYGUR ${ }^{3}$,Tuğba KAYA ${ }^{4}$}

${ }^{1}$ Hatay Mustafa Kemal University, Faculty of Health Sciences, Antakya / Turkey

${ }^{2}$ Sivas Cumhuriyet University, Faculty of Pharmacy, Department of Pharmaceutical Botany, Sivas / Turkey

${ }^{3}$ Selcuk University, faculty of Pharmacy, Department of Pharmacognosy, Konya / Turkey

${ }^{4}$ Hatay Mustafa Kemal University, Faculty of Medicine, Department of Parasitology Antakya / Turkey

\section{ORCID ID: 0000-0002-7317-885X', 0000-0001-8154-0874², 0000-0002-4674-70093, 0000-0001-7612-5414}

Öz: Amaç: Bu çalışmada, Hypericum scabrum'un metronidazole duyarlı ve dirençli Trichomonas vaginalis'ler üzerine etkisinin araştırılması amaçlandı. Yöntem: Hypericum scabrum örnekleri Sivas-Ankara karayolundan toplandı. Toprak üstü kısımları kurutularak masserasyon yöntemi ile methanol ekstaksiyonu yapıldı. Elde edilen ekstraktlara GC-MS analizi yapılarak olasi etken maddeler tespit edildi. Trichomonas vaginalis susar $5 \mathrm{mg} / \mathrm{mL}, 2.5 \mathrm{mg} / \mathrm{mL}, 1.25 \mathrm{mg} / \mathrm{mL}, 0.6 \mathrm{mg} /$ $\mathrm{mL}, 0.3 \mathrm{mg} / \mathrm{mL}, 0.15 \mathrm{mg} / \mathrm{mL}$ konsantrasyonlarda bitki ekstraktları ile muamele edildi. Bulgular: Metronidazol dirençli Trichomonas vaginalis suşalarının Minimum İnhibisyon Konsantrasyonu 2 saatlik bir muamele sonunda $2.5 \mathrm{mg} / \mathrm{mL}, 4$ saatlik muamele sonunda ise $1.25 \mathrm{mg} / \mathrm{mL}$ lik konsantrasyonlarda olduğu görüldü. $\mathrm{Bu}$ very metronidazole duyarlı suşlarda ise 2 saat sonunda $2.5 \mathrm{mg} / \mathrm{mL}$, 4 saat sonunda ise $<0.15 \mathrm{mg} / \mathrm{mL}$ olarak tespit edildi. Sonuç: Hypericum scabrum'un özellikle metronidazole dirençli suşlar üzerindeki etkisi oldukça önemlidir. Bulgularımız bu bitkinin yeni ilaç aktif bileşik izolasyonu için kullanılabileceği düşündürmektedir.

Anahtar Kelimeler: Hypericum Scabrum, Anti-Trichomonas Aktivite, GC-MS
Abstract: Aim: The objective of the study to evaluate the methanolic extracts of aerial parts of Hypericum scabrum L. for in vitro anti-trichomonase activity. Methods: Plant material were collected during the flowering period from natural populations in Sivas province of Turkey. Collected locality is: B6 Sivas: Sivas-Ankara road. The extracts obtained were analyzed by GC-MS to identify possible active substances. Trichomonas vaginalis strain was exposed with plant extracts at concentrations of $5 \mathrm{mg} / \mathrm{mL}, 2.5 \mathrm{mg} / \mathrm{mL}, 1.25 \mathrm{mg} / \mathrm{mL}$, $0.6 \mathrm{mg} / \mathrm{mL}, 0.3 \mathrm{mg} / \mathrm{mL}, 0.15 \mathrm{mg} / \mathrm{mL}$. Result: The minimum inhibitory concentration (MIC) was found to be $2.5 \mathrm{mg}$ $\mathrm{mL}$ at the end of 2 hours, $1.25 \mathrm{mg} / \mathrm{mL}$ at the end of 4 hours, and $0.6 \mathrm{mg} / \mathrm{mL}$ at the end of 24 hours after resistant T. vaginalis strains exposed to $\mathrm{H}$. scabrum methanol extract. When susceptible strains are to investigated, at the end of 2 hours the MIC value of $2.5 \mathrm{mg} / \mathrm{mL}$ is the lowest dose to the study, at 4 hours later even at the concentration of $0.15 \mathrm{mg} / \mathrm{mL}$, no live parasite is found. Conclusion: The obtained results suggest that the finding can used to further bio-assay guided active compound isolation from this plant as promising resource.

Key Words: Hypericum Scabrum, Anti-Trichomonas Activity, GC-MS

Doi: 10.17363/SSTB.2020.34.2

(1) Sorumlu Yazar, Corresponding Author: Necati OZPINAR “Dr. Öğgr. Üye. Assist. Prof”, Hatay Mustafa Kemal University, Faculty of Health Sciences, Antakya / Turkey, necatiozpinar@gmail.com, Geliş Tarihi / Received: 21.12.2019, Kabul Tarihi / Accepted: 19.03.2020, Makalenin Türü: Type of Article: (Araştırma-Uygulama; Research-Application) Çıkar Çatısması, Yok - Conflict of Interest, No, Etik Kurul Raporu veya Kurum İzin Bilgisi- Ethical Board Report or Institutiunal Approval, No 


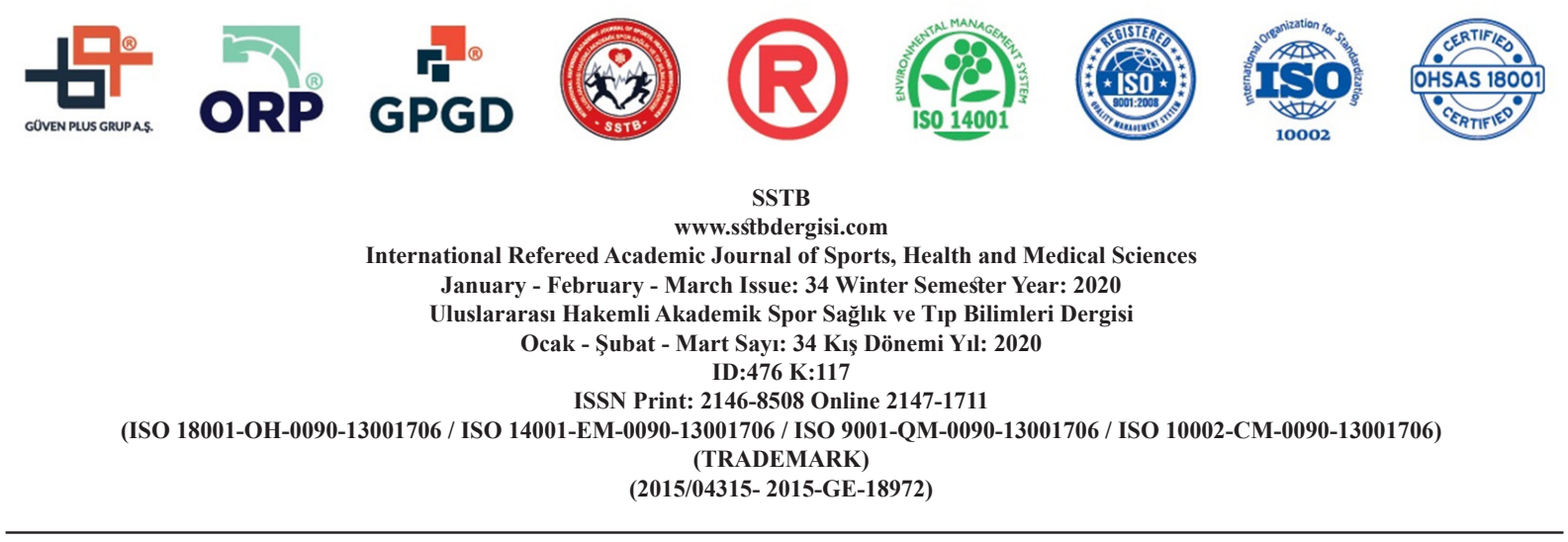

\section{INTRODUCTION}

The genus Hypericum (Hypericaceae) is represents by more than 400 species throughout the world, is mainly distributed in the Mediterranean and the Near East area (Simpson, 2006:122). In turkey, Hypericum is comprises of 96 species, in which half of them are endemic (Guner et al., 2000:2-28; Tekin, 2017:143152). Hypericum species are known for the local name of "sarı kantaron" and "binbir delik out", have been used for treatment of wound healing, sedative, antiulcer, antidiabetic, antispasmodic and antiseptic in Turkish folk medicine (Bingol et al., 2011:86-90). Phytochemical investigations on Hypericaceae revealed that they contain naphthodiantrones (hypericin and pseudohypericin), acylphloroglucinol derivatives (hyperforin and adhyperforin), flavonoids, tannins, and essential oils (Maggi et al., 2004:702-711; Zorzetto et al., 2015:95-109). The major components in fatty acids of $H$. scabrm L. were $\alpha$-linolnic, linoleic and oleic acid (Ozen and Bashan, 2003:723726). It was reported that $\alpha$-Pinene, $\beta-\mathrm{Pi}-$ nene, spathulenol, $p$-cymene, acetophenone, and carvacrol were the main constituents of the essential oil of H. scabrum (Tabanca et al., 2015:62-72). Studies have shown that Hypericum species have many biological activities such as antioxidant (Boga et al., 2016:249257; Mandrone et al., 2015:402-408; Silva et al., 2005:157-167), antimicrobial (Boga et al., 2016:249-257), cytotoxicity (Tala et al., 2015:149-155) and enzyme inhibition activity (Mandrone et al., 2015:402-408). In spite of many biological activity study on Hypericum spesices, there was little study on $H$. scabrum L.

Trichomoniasis is a most common protozoan infectious disease of the urogenital tract of humans caused by Trichomonas vaginalis ( $T$. vaginalis), which is the reason why the rate of illness is high in women who have reached sexual maturity. T. vaginalis, an anaerobic protozoan that causes trichomoniasis in humans, moves by itself with a whip and waving membrane. Trichomonal infection has a cosmopolitan distribution and is detected in all racial groups and socioeconomic layers. Approximately 333 million new Sexually Transmitted Diseases (STDs) occur annually in the world, of which 170 million are T. vaginalis infections (WHO, 2012). Metronidazole is the only drug for therapy of this disease approved by FDA. However, metronidazole has been reported for the resistance by T. vaginalis (Kirkcaldy et al., 2012:939; Schwebke and Barrientes, 2006:4209-4210; Snipes et al., 2000:3004-3009).

The aim of the present study focuses on the investigation of anti-Ttrichomonase activity of $H$. scabrum methanol extract. 
International Refereed Academic Journal of Sports, Health and Medical Sciences

January - February - March Issue: 34 Winter Semester Year: 2020

Uluslararası Hakemli Akademik Spor Sağlık ve Tıp Bilimleri Dergisi Ocak - Şubat - Mart Sayı: 34 Kış Dönemi Yıl: 2020 ID:476 K:117

ISSN Print: 2146-8508 Online 2147-1711

(ISO 18001-OH-0090-13001706 / ISO 14001-EM-0090-13001706 / ISO 9001-QM-0090-13001706 / ISO 10002-CM-0090-13001706) (TRADEMARK)

(2015/04315- 2015-GE-18972)

\section{MATERIAL and METHODS}

GC-MS analysis was performed by GRUMLAB (Giresun University Center Research Laboratory, Application and Research Center)

\section{Plant Materials}

Plant material were collected during the flowering period from natural populations in Sivas province of Turkey. Collected locality is: B6 Sivas: Sivas-Ankara road, $25 \mathrm{~km}$.

\section{Preparation of the Extracts}

The dried plant materials were powderd using a grinder. The extraction was done at room temperature. $10 \mathrm{~g}$ of dried and grounded herbs were extracted with methanol (250 $\mathrm{mL} \times 4$ ) for $24 \mathrm{~h}$ with intermittent shaking. Then mixture were filtered through a filter paper (Whatman, No.1). The filtrates combined together and concentrated under vaccum on a rotary evaporator (Buchi R-100 equipped with Vacuum Pump V-300 and Control unit I-300) at $40^{\circ} \mathrm{C}$ and stored at $-20^{\circ} \mathrm{C}$ for further processing. The yields of crude methanol extracts of $H$. scabrum was obtained as $18.9 \%$.

\section{Anti-Trichomonase Vaginalis Activity}

The metronidazole-resistant $T$. vaginalis ATCC 50143 and the metronidazole-sensitive strain, T. vaginalis ATCC50148 strain (obtained by Amerikcan Type Culture Collection (ATCC) were used in this study.

\section{Culture of Trichononase Vaginalis}

Trichomonas Broth (TB, liofilchem, 610061) medium was purchased commercially and was prepared according to the manufacturer's instructions. After preparation of the TB, it was distributed among the experimental tubes and placed in the autoclave at $121^{\circ} \mathrm{C}$ for 15 mins, then cooled to $37^{\circ} \mathrm{C}$, and $10 \%$ inactive horse serum (Sigma, 1234598765) was added to the medium. The $T$. vaginalis strains were added to the TB medium and incubated for 3 days at $37^{\circ} \mathrm{C}$ under anaerobic conditions.

\section{In Vitro Anti-Trichomonas Assay}

The Minimum Lethal Dose (MLD) of the metronidazole-sensitive strain, $T$. vaginalis ATCC50148, and the metronidazole-resistant strain, T. vaginalis ATCC50143 against metronidazole was tested in comparison with the plant extract. For this purpose, 96-well plates were used. The $T$. vaginalis strains produced from seeding in the TB medium at $37^{\circ} \mathrm{C}$ were incubated in metronidazole (Sigma, 1711544348111) concentrations of $400 \mu \mathrm{M}$, $200 \mu \mathrm{M}, 100 \mu \mathrm{M}, 50 \mu \mathrm{M}, 25 \mu \mathrm{M}, 12,5 \mu \mathrm{M}$, $0,6 \mu \mathrm{M}$ and $0,3 \mu \mathrm{M}$. and plant exract concentration $5 \mathrm{mg} / \mathrm{mL}, 2.5 \mathrm{mg} / \mathrm{mL}, 1.25 \mathrm{mg} / \mathrm{mL}$, $0.6 \mathrm{mg} / \mathrm{mL}, 0.3 \mathrm{mg} / \mathrm{mL}, 0.15 \mathrm{mg} / \mathrm{mL}$ After 2-4-24 h, the incubated live protozoa were checked on a Thoma slide for flagellated and 
SSTB

www.sstbdergisi.com

International Refereed Academic Journal of Sports, Health and Medical Sciences

January - February - March Issue: 34 Winter Semester Year: 2020

Uluslararası Hakemli Akademik Spor Sağık ve Tıp Bilimleri Dergisi

Ocak - Şubat - Mart Sayı: 34 Kış Dönemi Yıl: 2020 ID:476 K:117

ISSN Print: 2146-8508 Online 2147-1711

(ISO 18001-OH-0090-13001706 / ISO 14001-EM-0090-13001706 / ISO 9001-QM-0090-13001706 / ISO 10002-CM-0090-13001706) (TRADEMARK)

(2015/04315- 2015-GE-18972)

undulating membrane movement and were counted in a $1 \%$ eosin solution. A dose where no live parasites were found was determined microscopically and evaluated as MLD.

\section{RESULTS}

\section{Chemical Composition by GC-MS Analyasis}

The chemical compositions of methanol extract of Hypericum scabrum aerial parts have been determined by GC-MS (Table 1). The methanol extract was found to have a higher component content. While the most abundant components are palmitic acid (8.78 $\%$, benzoic acid (2.97\%), and -1-carbaldehyde $(2.01 \%)$ for methanol extract (Table 1$)$. Among the compounds, the 4H-Pyran-4-one are important for the biosynthesis of the hypericin that are main compound of Hypericum species. 
www.sstbdergisi.com

International Refereed Academic Journal of Sports, Health and Medical Sciences

January - February - March Issue: 34 Winter Semester Year: 2020

Uluslararası Hakemli Akademik Spor Sağlık ve Tıp Bilimleri Dergisi

Ocak - Şubat - Mart Sayı: 34 Kış Dönemi Yıl: 2020 ID:476 K:117

ISSN Print: 2146-8508 Online 2147-1711

(ISO 18001-OH-0090-13001706 / ISO 14001-EM-0090-13001706 / ISO 9001-QM-0090-13001706 / ISO 10002-CM-0090-13001706) (TRADEMARK)

(2015/04315- 2015-GE-18972)

Table 1. Chemical Compositions of Methanol Extracts of Hypericum scabrum

\begin{tabular}{lll}
\hline Components & RT & Methanol (\%) \\
\hline Ethanone & 14.268 & 0.65 \\
\hline Benzoic acid & 15.212 & 2.97 \\
\hline 4H-Pyran-4-one & 17.054 & 1.37 \\
\hline Isopropyl phenyl ketone & 27.542 & 1.74 \\
\hline Naphthalene & 28.435 & 0.27 \\
\hline Dodecanoic acid & 30.867 & 0.36 \\
\hline Spathulenol & 31.147 & 0.33 \\
\hline Hexadecanoic acid & 37.773 & 0.90 \\
\hline Palmitic acid & 38.792 & 8.78 \\
\hline Furo[2,3-b]quinolin-4(9H)-one & 40.091 & 1.28 \\
\hline 4,1-herbertenolide & 40.354 & 0.46 \\
\hline 9-Octadecenoic acid & 40.600 & 0.79 \\
\hline 9,12-Octadecadienoic acid & 41.527 & 1.70 \\
\hline (1RS,2SR)-2-methyl-2-4'-methylpen-1-carbaldehyde & 42.116 & 2.01 \\
\hline trans-Geranylgeraniol & 43.587 & 0.73 \\
\hline Tetracosane & 46.093 & 0.65 \\
\hline Geranyl-linalol & 46.242 & 0.78 \\
\hline Octadecane & 49.137 & 0.28 \\
\hline Ent-beyer-15-en-18-ol & 57.383 & 1.25 \\
\hline
\end{tabular}

\section{Anti-Trichomonase vaginalis activity}

The effect of $H$. scabrum methanol extract on metronidazole susceptible and resistant T. vaginalis strains is shown in Table 2 . The minimum inhibitory concentration (MIC) was found to be $2.5 \mathrm{mg} / \mathrm{mL}$ at the end of 2 hours, $1.25 \mathrm{mg} / \mathrm{mL}$ at the end of 4 hours, and 0.6 $\mathrm{mg} / \mathrm{mL}$ at the end of 24 hours after resistant T. vaginalis strains exposed to $H$. scabrum methanol extract. When susceptible strains are to investigated, at the end of 2 hours the MIC value of $2.5 \mathrm{mg} / \mathrm{mL}$ is the lowest dose to the study, at 4 hours later even at the concentration of $0.15 \mathrm{mg} / \mathrm{mL}$, no live parasite is found (Table 2). 


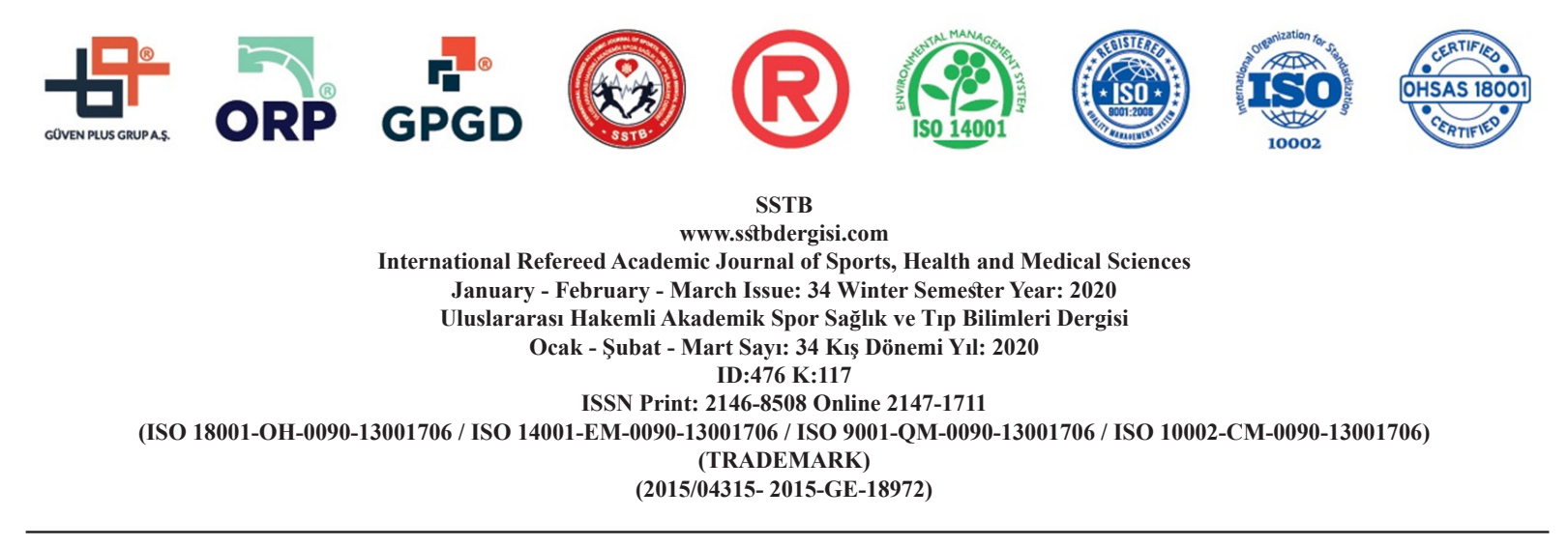

Table 2. The Viable Counts of $\boldsymbol{T}$. Vaginalis Isolates Exposed to Different Concentrations of Metronidazole at the End of 2, 4 and 24 Hours

\begin{tabular}{|c|c|c|c|c|c|c|c|c|c|c|}
\hline \multirow{2}{*}{$\begin{array}{c}\text { TV } \\
\text { strains }\end{array}$} & & \multicolumn{9}{|c|}{ Metronidazol Concentration } \\
\hline & & $\begin{array}{l}400 \\
\mu \mathrm{M}\end{array}$ & $\begin{array}{l}200 \\
\mu \mathrm{M}\end{array}$ & $\begin{array}{l}100 \\
\mu \mathrm{M}\end{array}$ & $\begin{array}{c}50 \\
\mu \mathrm{M}\end{array}$ & $\begin{array}{c}25 \\
\mu \mathrm{M}\end{array}$ & $\begin{array}{l}12.5 \\
\mu \mathrm{M}\end{array}$ & $0.6 \mu \mathrm{M}$ & $0.3 \mu \mathrm{M}$ & Control \\
\hline N1 & \multirow{2}{*}{$2 \mathrm{~h}$} & $14.10^{3}$ & $14.10^{3}$ & $14.10^{3}$ & $15.10^{3}$ & $17.10^{3}$ & $18.10^{3}$ & $18.10^{3}$ & $18.10^{3}$ & $18.10^{3}$ \\
\hline N2 & & 0 & 0 & 0 & 0 & 0 & $6.10^{3}$ & $8.10^{3}$ & $12.10^{3}$ & $17.10^{3}$ \\
\hline N1 & \multirow{2}{*}{$4 \mathrm{~h}$} & $14.10^{3}$ & $14.10^{3}$ & $14.10^{3}$ & $15.10^{3}$ & $17.10^{3}$ & $18.10^{3}$ & $18.10^{3}$ & $18.10^{3}$ & $18.10^{3}$ \\
\hline N2 & & 0 & 0 & 0 & 0 & 0 & 0 & $6.10^{3}$ & $10.10^{3}$ & $18.10^{3}$ \\
\hline N1 & \multirow{2}{*}{$24 \mathrm{~h}$} & $14.10^{3}$ & $16.10^{3}$ & $16.10^{3}$ & $18.10^{3}$ & $18.10^{3}$ & $20.10^{3}$ & $20.10^{3}$ & $20.10^{3}$ & $20.10^{3}$ \\
\hline N2 & & 0 & 0 & 0 & 0 & 0 & 0 & 0 & $12.10^{3}$ & $22.10^{3}$ \\
\hline \multirow{2}{*}{$\begin{array}{c}\text { TV } \\
\text { strains }\end{array}$} & & \multicolumn{9}{|c|}{ H. scabrum methanol extract concentration } \\
\hline & & $\begin{array}{c}5 \\
\mathrm{mg} / \mathrm{mL}\end{array}$ & $\begin{array}{r}2 \\
\mathrm{mg}\end{array}$ & & $\begin{array}{c}1.25 \\
\mathrm{mg} / \mathrm{mL}\end{array}$ & $\begin{array}{c}0.6 \\
\mathrm{mg} / \mathrm{mL}\end{array}$ & $\begin{array}{c}0.3 \\
\mathrm{mg} / \mathrm{mL}\end{array}$ & & $\begin{array}{l}0.15 \\
\mathrm{gg} / \mathrm{mL}\end{array}$ & Control \\
\hline N1 & \multirow{2}{*}{$2 \mathrm{~h}$} & 0 & \multicolumn{2}{|c|}{0} & $2.10^{3}$ & $4.10^{3}$ & $10.10^{3}$ & & $0.10^{3}$ & $18.10^{3}$ \\
\hline N2 & & 0 & \multicolumn{2}{|c|}{0} & $1.10^{3}$ & $2.10^{3}$ & $5.10^{3}$ & & $2.10^{3}$ & $17.10^{3}$ \\
\hline N1 & \multirow{2}{*}{$4 \mathrm{~h}$} & 0 & \multicolumn{2}{|c|}{0} & 0 & $2.10^{3}$ & $3.10^{3}$ & & $7.10^{3}$ & $18.10^{3}$ \\
\hline N2 & & 0 & \multicolumn{2}{|c|}{0} & 0 & 0 & 0 & & 0 & $18.10^{3}$ \\
\hline N1 & \multirow{2}{*}{$24 \mathrm{~h}$} & 0 & \multicolumn{2}{|c|}{0} & 0 & 0 & $2.10^{3}$ & & $7.10^{3}$ & $20.10^{3}$ \\
\hline N2 & & 0 & \multicolumn{2}{|c|}{0} & 0 & 0 & 0 & & 0 & $22.10^{3}$ \\
\hline
\end{tabular}

TV; Trichomonas vaginalis, N1; T. vaginalis ATCC50143 Resistance to Metronidazol, N2; T. vaginalis ATCC50148 Sentitive to Metronidazol.

\section{DISCUSSION}

The T. vaginalis is a sexually transmissible protozoan parasite and common all over the world and is found in every continent and climate and It is the commonest curable sexually transmitted infection. The prevalence of infection varies according to the way of living and socio-cultural structure of the society. The frequency of $T$. vaginalis infection in men is not well defined, because it is usually asymptomatic and the source of continuous infection are asymptomatic men (Petrin et al., 1998:300-317).

In recent studies, this parasite has become more important as it has been found to increase the transmission rate of HIV (Polat et al., 2011:35-68). 
International Refereed Academic Journal of Sports, Health and Medical Sciences

January - February - March Issue: 34 Winter Semester Year: 2020

Uluslararası Hakemli Akademik Spor Sağlık ve Tıp Bilimleri Dergisi

Ocak - Şubat - Mart Sayı: 34 Kış Dönemi Yıl: 2020 ID:476 K:117

ISSN Print: 2146-8508 Online 2147-1711

(ISO 18001-OH-0090-13001706 / ISO 14001-EM-0090-13001706 / ISO 9001-QM-0090-13001706 / ISO 10002-CM-0090-13001706) (TRADEMARK)

(2015/04315- 2015-GE-18972)

In studies in Turkey, $5-10 \%$ in healthy women who went to private clinics $T$. vaginalis was detected. In addition, $13-25 \%$ of women admitted to the gynecology and obstetrics clinic and $50-70 \%$ of women working in brothels and women's prisons were detected (Culha et al., 2006:16-18).

Metronidazole-containing preparations are often used in the treatment of trichomoniasis. However, recently metranidazole has failed in some patients when not combined with another antibiotic, and in some patients the recurrence of the disease after a short time suggests two things. The first is that the disease is not caused by T. vaginalis. The second is that $T$. vaginalis has developed resistance to its medication like many living things. Although resistance studies are not sufficient, such studies have been encountered in recent years.

According to studies in the United States, metronidazole resistant $T$. vaginalis has been reported at rates varying between $4.3 \%$ and 9.6\% (Kirkcaldy et al., 2012:939). In another study in Finland, 10 clinical isolates were tested positive for metronidazole resistance of these, $3(30,0 \%)$ resistant strains were identified (Meri et al., 2000:763-767). In a 2018 study in Turkey, metronidazole resistance was tested using conventional and molecular methods and resistant isolates were determined at a rate of $33.3 \%$ (Ozcelik et al., 2018:188-194).

Hypericum scabrum is widely used in alternative medicine. However, we have not found any study on the antiprotozoal effect of $\mathrm{Hy}$ pericum scabrum on T. vaginalis in literature. In our study, the effect of Hypericum scabrum on metronidazole resistant $T$. vaginalis strains is of great importance.

\section{CONCLUSION}

It is important to underline the fact that this is the first report about the anti- $T$. vaginalis activity on Hypericum scabrum methanol extract. The obtained results suggest that the finding can used to further bio-assay guided active compound isolation from this plant as promising resource.

\section{Conflict of interest}

The authors declare that there is no conflict of interest.

\section{REFERENCES}

BINGOL, U., COSGE, B., GURBUZ, B., (2011). Hypericum species in flora of Turkey. Hypericum. Medicinal and Aromatic Plant Science and Biotechnology $5,86-90$

BOGA, M., ERTAS, A., EROGLU-OZKAN, E., KIZIL, M., CEKEN, B., TOPCU, G., (2016). Phytochemical analysis, anti- 
International Refereed Academic Journal of Sports, Health and Medical Sciences

January - February - March Issue: 34 Winter Semester Year: 2020

Uluslararası Hakemli Akademik Spor Sağlık ve Tıp Bilimleri Dergisi

Ocak - Şubat - Mart Sayı: 34 Kış Dönemi Yıl: 2020 ID:476 K:117

ISSN Print: 2146-8508 Online 2147-1711

(ISO 18001-OH-0090-13001706 / ISO 14001-EM-0090-13001706 / ISO 9001-QM-0090-13001706 / ISO 10002-CM-0090-13001706) (TRADEMARK)

(2015/04315- 2015-GE-18972)

oxidant, antimicrobial, anticholinesterase and DNA protective effects of Hypericum capitatum var. capitatum extracts. South African Journal of Botany 104, 249-257

CULHA, G., HAKVERDI, A.U., ZETEROGLU, S., DURAN, N., (2006). Investigation of the prevalence of Trichomonas vaginalis in women with complaints of vaginal discharge and Itching. Turkiye Parazitoloji Dergisi. 30, 16-18

GUNER, A., OZHATAY, N., EKIM, T., BAS$\boldsymbol{E R}, \boldsymbol{K}$., (2000). Flora of Turkey and the east Aegean Islands. Supplement 2, 28

KIRKCALDY, R.D., AUGOSTINI, P., ASBEL, L.E., BERNSTEIN, K.T., KERANI, R.P., METTENBRINK, C.J., et, al., (2012). Trichomonas vaginalis antimicrobial drug resistance in 6 US cities, STD Surveillance Network, 2009-2010. Emerging Infectious Diseases 18, 939

MAGGI, F., FERRETTI, G., POCCESCHI, N., MENGHINI, L., RICCIUTELLI, M., (2004). Morphological, histochemical and phytochemical investigation of the genus Hypericum of the Central Italy. Fitoterapia 75, 702-711

MANDRONE, M., LORENZI, B., VENDITTI, A., GUARCINI, L., BIANCO, A., SANNA, C., et, al., (2015). Antioxidant and anti-collagenase activity of $H y$ - pericum hircinum L. Industrial Crops and Products 76, 402-408

MERI, T., JOKIRANTA, T.S., SUHONEN, L., MERI, S., (2000). Resistance of Trichomonas vaginalis to metronidazole: report of the first three cases from Finland and optimization of in vitro susceptibility testing under various oxygen concentrations. Journal of Clinical Microbiology $38,763-767$

OZCELIK, S., OZPINAR, N., KARAKUS, S., AKYILDIZ, F., KARAKAYA, O., (2018). Metronidazole resistance in Trichomonas vaginalis determined by molecular and conventional methods. Tropical Biomedicine 35, 188-194

OZEN, H.C., BASHAN, M., (2003). The composition of fatty acids in Hypericum scabrum, H. scabroides and $H$. amblysepalum. Turkish Journal of Chemistry 27, 723-726

PETRIN, D., DELGATY, K., BHATT, R., GARBER, G., (1998). Clinical and microbiological aspects of Trichomonas vaginalis. Clinical Microbiology Reviews $11,300-317$

POLAT, E., SIREKBASAN, S., YILDIRIM, Z., BAGDATLI, Y., CEPNI, I., CIFT, T., et, al., (2011). Comparing the occurrence of Trichomonas vaginalis infections to- 
International Refereed Academic Journal of Sports, Health and Medical Sciences

January - February - March Issue: 34 Winter Semester Year: 2020

Uluslararası Hakemli Akademik Spor Sağlık ve Tıp Bilimleri Dergisi

Ocak - Şubat - Mart Sayı: 34 Kıș Dönemi Yıl: 2020 ID:476 K:117

ISSN Print: 2146-8508 Online 2147-1711

(ISO 18001-OH-0090-13001706 / ISO 14001-EM-0090-13001706 / ISO 9001-QM-0090-13001706 / ISO 10002-CM-0090-13001706) (TRADEMARK)

(2015/04315- 2015-GE-18972)

day to ten years ago among women prostitutes and gynecology and obstetrics patients. Türkiye Parazitolojii Dergisi 35-68

SCHWEBKE, J.R., BARRIENTES, F.J., (2006). Prevalence of Trichomonas vaginalis isolates with resistance to metronidazole and tinidazole. Antimicrobial Agents and Chemotherapy 50, 4209-4210

SILVA, B.A., FERRERES, F., MALVA, J.O., DIAS, A.C., (2005). Phytochemical and antioxidant characterization of Hypericum perforatum alcoholic extracts. Food Chemistry 90, 157-167

SIMPSON, M., (2006). Phylogenetic Systematics. Plant Systematics. Elsevier academic press, Cannada

SNIPES, L.J., GAMARD, P.M., NARCISI, E.M., BEARD, C.B., LEHMANN, T., SECOR, W.E., (2000). Molecular epidemiology of metronidazole resistance in a population of Trichomonas vaginalis clinical isolates. Journal of Clinical Microbiology 38, 3004-3009

TABANCA, N., DEMIRCI, B., ALI, A., I KHAN, S., R JACOB, M., AYTAC, Z., et, al., (2015). Chemical composition, biting deterrent, antimalarial and antimicrobial activity of essential oil from Hypericum scabrum L. Current Bioactive Compounds $11,62-72$

TALA, M.F., TALONTSI, F.M., ZENG, G.Z., WABO, H.K., TAN, N.-H., SPITELLER, M., et, al., (2015). Antimicrobial and cytotoxic constituents from native cameroonian medicinal plant Hypericum riparium. Fitoterapia 102, 149-155

TEKIN, M., (2017). Pharmacobotanical study of Hypericum thymopsis. Revista Brasileira de Farmacognosia 27, 143-152

WHO., (2012). Global incidence and prevalence of selected curable sexually transmitted infections-2008. World Health Organization

ZORZETTO, C., SÁNCHEZ-MATEO, C.C., RABANAL, R.M., LUPIDI, G., PETRELLI, D., VITALI, L.A., et, al., (2015). Phytochemical analysis and in vitro biological activity of three Hypericum species from the Canary Islands ( $\mathrm{Hy}$ pericum reflexum, Hypericum canariense and Hypericum grandifolium). Fitoterapia 100, 95-109 